J. Lake Sci. (湖泊科学), 2006, 18(6):636-642

http:// www. jlakes. org. E-mail: jlakes@ niglas. ac.cn

(c) 2006 by Journal of Lake Sciences

\title{
太湖北部湖区水体中浮游细菌的动态变化
}

\author{
冯 胜 ${ }^{1,2}$, 高 光 $^{1}$, 秦伯强 ${ }^{1}$, 陈 默 ${ }^{1,2}$
}

( 1 : 中国科学院南京地理与湖泊研究所,南京 210008)

(2: 中国科学院研究生院, 北京 100049)

摘 要:2003 年 1 月 -12 月对太湖北部湖区 8 个采样点进行了每月 1 次、为期一年的水体中浮游细菌数量的测定,并同 步对溶解性有机碳 (DOC), 总氮, 总磷, 叶绿素 $\mathrm{a}$ 和温度进行了测定, 结果表明: 浮游细菌数量存在明显的季节变化和空间 差异,夏秋季浮游细菌数量比冬春季高, 最高值出现在夏季的 7 月份, 平均值为 $7.43 \times 10^{6} \mathrm{cell} / \mathrm{ml}$, 最低值出现在 3 月份, 平均值为 $3.14 \times 10^{6} \mathrm{cells} / \mathrm{ml}$, 最低值与最高值差异达 $73 \%$; 污染严重的河口区浮游细菌数量明显高于湖心区, 最高值出现 在河口的 $6^{\#}$ 点,平均值为 $5.51 \times 10^{6} \mathrm{cells} / \mathrm{ml}$, 比湖心区最低值 $8^{\#}$ 点高 $83.2 \%$, 并呈现从河口、湾内至湖心随水体污染程度 减轻而逐步递减的趋势; 浮游细菌数量与温度和浮游植物量显著相关, 而与水体中营养盐无关, 预示着太湖水体中的营养 盐已处于较高的水平, 不再是浮游细菌生长的限制因素, 而来源于浮游植物的有机碳可能是其生长的重要碳源.

关键词: 浮游细菌; 环境因子; 太湖

\section{Variability of bacterioplankton in the north zone of Lake Taihu}

FENG Sheng $^{1,2}$, GAO Guang ${ }^{1}$, QIN Boqiang ${ }^{1} \&$ CHEN Mo ${ }^{1,2}$

( 1 :Nanjing Institute of Geography and Limnology, Chinese Academy of Sciences, Nanjing 210008, P. R. China) (2: Graduate School of Chinese Academy of Sciences, Beijing 100039, P. R. China)

\begin{abstract}
Bacterioplankton are not only decomposers of organic material but also secondary producers in water ecosystems. They are abundant and dynamic members of remobilization of organic carbon and regeneration of inorganic nutrients in water environments. This paper presents the seasonal variation in the abundance of bacterioplankton and the difference in different zone, the relationship between the environmental factors and the abundance of bacterioplankton in the North Lake Taihu from January to December in 2003 , the results showed that the number of bacterioplankton changes with the seasons. With the increase of water temperature, the number of bacterioplankton in the water increases, the smallest value in winter, and the largest value in summer. The number of bacterioplankton was closely correlated with the concentration of chlorophyll a $\left(r^{2}=0.8301, n=12, P<0.01\right)$ and water temperature $\left(r^{2}=0.463, n=12, P<0.01\right)$ respectively, but has no correlation with the nutriment. The results indicate that the nutrimental substance is very high in Lake Taihu, and is not be the limiting factrs for bacterioplankton ; the DOC is an important source for bacterioplankton which comes from the phytoplankton.
\end{abstract}

Keywords : Bacterioplankton; environmental factors; Lake Taihu

微生物既是营养物质的分解者和转化者, 又是物质和能量的它存者, 同时还是食物链中重要的生产者, 微食物环 (microbial loop $)^{[1,2]}$ 的发现为生源要素的生物地球化学循环研究带来了概念上和理论上的突 破 ${ }^{[3]}$. 微生物群落不仅常常在生物量上占优势, 而且其转换效率也高, 构成了生态系统能流网中具有特殊 意义的一环 ${ }^{[4]}$. 由于微生物既可将颗粒有机碳 (POC) 分解转化为溶解性有机碳 (DOC), 并进一步矿化为营 养盐供浮游植物利用, 又可吸收 DOC 合成自身成分, 所形成的细胞颗粒通过浮游动物的摄食进人上一营养

* 中国科学院知识创新工程重大项目 (KZCX1 - SW - 12)、国家高技术研究发展计划项目 (863) (2002AA60101104 ) 共同资助. 2005-11-20 收稿;2006-01-18 收修改稿. 冯胜,男,1975 年生,博士研究生, E-mail: shfeng@niglas. ac. cn. 
级. 可见, 水体中浮游细菌的生存及生命活动决定着其中食物链基本环节的发展 ${ }^{[5,6]}$, 浮游细菌在水域生态 系统中的作用及影响因素的研究正日益受到重视,许多学者对控制浮游细菌数量及生态分布控制机理进行 了大量的研究, 并取得了一定的进展 ${ }^{[7]}$. 对水体浮游细菌数量、生物量或细菌生产力分布特征等的研究也 做了很多工作,但多数研究集中在海洋或河口区域 ${ }^{[6]}$. 运用苂光染色方法对湖泊水体中浮游细菌进行计数 研究的文章, 国内还少有报道.

进行湖泊水体细菌分布规律及影响因素的研究, 对于进一步了解湖泊微生物在物质和能量转化过程中 的作用机理以及对食物链的实际贡献, 为阐明湖泊富营养发生机理化具有极为重要的意义. 本文报道了太 湖北部湖区不同营养水平水体中浮游细菌的时空变化规律及其与水温、总氮 ( TN)、总磷 (TP)、溶解性有机 碳( DOC)、叶绿素a(Chla) 等生态环境因子的关系,试图探讨影响浮游细菌生长的关键因子.

\section{1 材料与方法}

\section{1 采样位点}

太湖 $\left(30^{\circ} 56^{\prime}-31^{\circ} 34^{\prime} \mathrm{N}, 119^{\circ} 54^{\prime}-120^{\circ} 36^{\prime} \mathrm{E}\right)$ 面积 $2338 \mathrm{~km}^{2}$, 最大水深 $2.6 \mathrm{~m}$, 平均水深 $1.9 \mathrm{~m}$, 是一典型 的浅水湖泊 ${ }^{[8]}$. 梅梁湾系太湖北部的一较大湖湾, 地处无锡市郊, 面积约 $132 \mathrm{~km}^{2}$, 平均水深 $2.0 \mathrm{~m}$. 是无锡 市主要旅游区及水源地. 由于受人湖河道及沿岸污染源的影响, 水质恶化, 夏秋季节整个湾内滋生大量蓝藻 水华, 属于典型的富营养化湖区. 2003 年 1 月 -12 月, 对入湖河口至湖心的 8 个采样点, 逐月采样, 根据其 地理位置, 采样点分为 3 为河口区 $\left(0^{\#} 、 6^{\#}\right)$,梅梁湾 $\left(1^{\# 、} 、 3^{\#} 、 4^{\#} 、 5^{\#}\right)$, 湖心区 $\left(7^{\#} 、 8^{\#}\right)($ 图 1$)$.

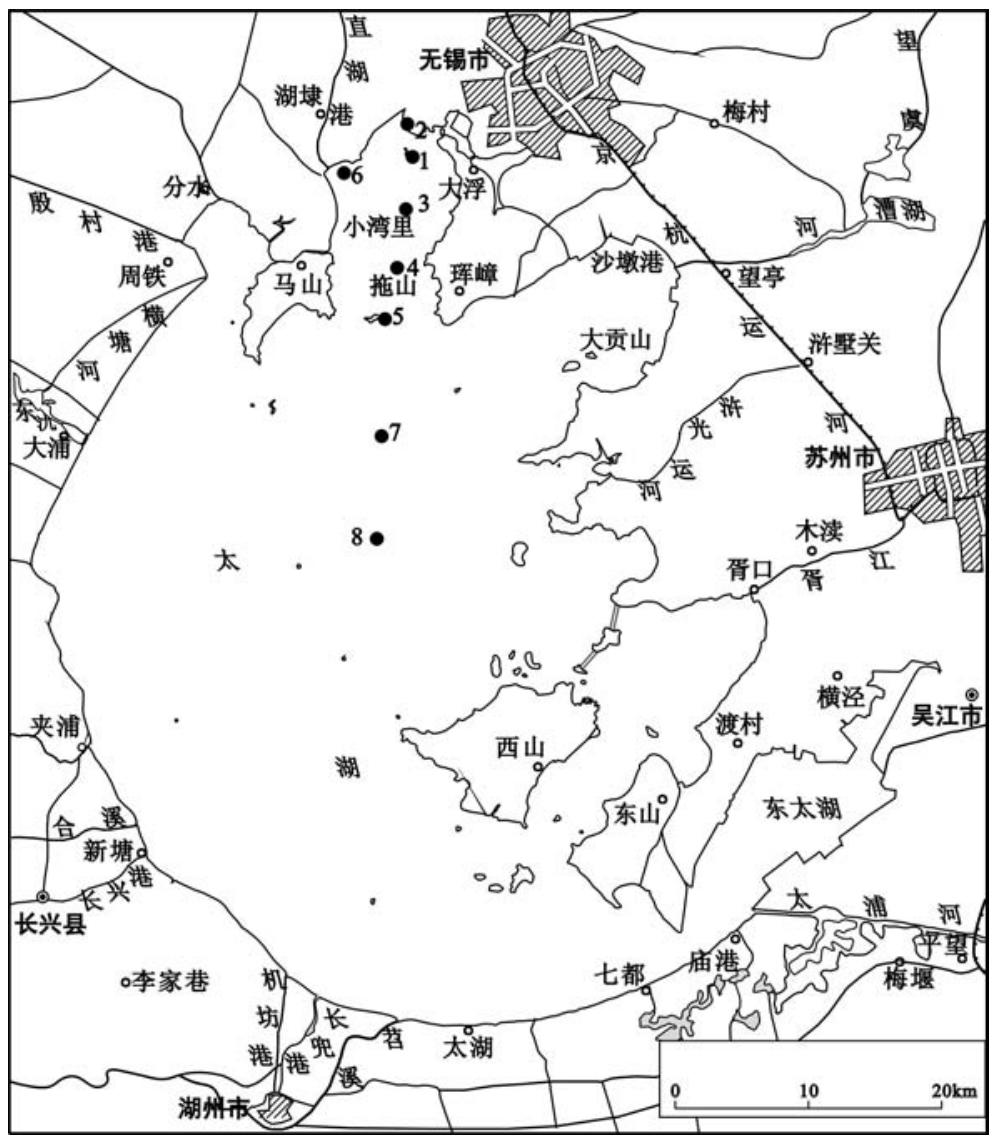

图 1 采样点位的分布

Fig. 1 The distribution of sampling station 


\section{2 样品的采集}

每月定点采集水样 1 次, 采集 $0.5 \mathrm{~m}$ 处左右水样,微生物样品的采集, 将水样注人经酸浸泡, 清洗干净, 预先灭菌的玻璃瓶中,加人无颗粒甲醛 (甲醛终浓度为 $2 \%$ ), 带回实验室 $4{ }^{\circ} \mathrm{C}$ 保存直至分析. 其它水样用预 先洗干净的塑料瓶采集.

\section{3 样品的分析}

1.3.1 异养细菌的计数方法 DAPI (4,6-diamidino-2-phenylindole Sigma) 染色: 将一张孔径 0.45 $\mu \mathrm{m}$, 直径 $25 \mathrm{~mm}$ 的滤膜放在玻璃滤器的砂芯上并用无颗粒水润湿, 然后在其上再放一张黑背景聚碳酸酯滤 膜 (Poretics, $0.22 \mu \mathrm{m}, \phi 25 \mathrm{~mm}$ ), 取适量水样, 加上适量的 DAPI 工作液染色一定时间,用手持真空泵在较低 压力下过滤, 将抽滤后滤膜转移至载玻片上, 加无苂光浸镜油, 盖上盖玻片. 用苂光显微镜 (Zeiss, $100 \mathrm{~W}$ HBO) 在放大倍数为 $16 \times 100$ 倍数下观察记数, 随机观测 $10-20$ 个视野, 每一张滤膜计数不少于 400 个细 胞, 然后将视野细菌数量转换为每毫升实际细菌细胞数 ( cells $/ \mathrm{ml}$ ), 即为浮游细菌丰度. 按 $N B=W A \times N \times F /$ $F A \times V$ 公式计算每立方厘米水样中总细菌数. 式中 $W A$ 为可利用的滤膜面积; $N$ 为每个视野细菌平均数; $F$ 为水样的稀释系数; $V$ 为过滤水样的体积立方厘米数.

\section{3 其它理化参数的测定}

温度现场用水温计直接测定; 总氮、总磷用紫外分光光度计测 ${ }^{\text {定 }}{ }^{[9]}$; 叶绿素 a 用 $90 \%$ 丙酮萃取苂光分 光光度法测定 ${ }^{[9]}$; DOC 用美国生产的 $1020 \mathrm{~A}$ 型 TOC 仪测定.

\section{4 数据处理}

所有实验数据均在 SPSS for windows (11.5) 统计软件上进行处理.

\section{2 结果}

\section{1 采样区域的水环境状况}

表 1 是各采样点的基本理化因子的分布状况,可以看出从 $8^{\#}$ 到 $0^{\#}$ 点,每个月各个采样点的温度差异不 是很大, 从湖心到河口区, 水温略有上升,但上幅度一般不超过 $2^{\circ} \mathrm{C}$; 不同季节水温差异较大;代表浮游植物 生物量的水体中叶绿素 $\mathrm{a}$ 的含量, 冬夏之间也有很大不同,并存在明显的空间差异. 季节上,叶绿素 a 含量 最高出现在夏季的 6 月份, 为 $31.96 \mu \mathrm{g} / \mathrm{L}$, 最低值出现在 3 月份, 为 $3.51 \mu \mathrm{g} / \mathrm{L}$, 仅为最高值的 $11 \%$. 空间上, 叶绿素 a 最大值出现在梅梁湾, 为 $23.43 \mu \mathrm{g} / \mathrm{L}$, 最低值出现湖心, 为 $7.82 \mu \mathrm{g} / \mathrm{L}$, 差异达 $67 \%$. 总氮、总磷和溶 解性有机碳含量的季节变化差异不大,但不同区域之间差别较大. 参照太湖富营养化程度评价标准 ${ }^{[10]}$ 的相 关指标, 从湖心到河口区 8 个取样点的富营养综合指数分别为: $71.16,73.96,74.01,74.90,76.47,81.13$, $87.71,85.03 ;$ 三个区域的水体均处于富营养到严重富营养的状态.

表 1 各采样点的基本理化因子的分布状况

Tab. 1 physical and chemical parameters of the sampling sites

\begin{tabular}{cccccccccccc}
\hline \multirow{2}{*}{ 采样区域 } & \multicolumn{2}{c}{ 温度 $\left({ }^{\circ} \mathrm{C}\right)$} & \multicolumn{2}{c}{ 总氮 $(\mathrm{mg} / \mathrm{L})$} & \multicolumn{2}{c}{ 总磷 $(\mathrm{mg} / \mathrm{L})$} & \multicolumn{2}{c}{ 叶绿素 $\mathrm{a}(\mu \mathrm{g} / \mathrm{L})$} & \multicolumn{2}{c}{ 总有机碳 $(\mathrm{mg} / \mathrm{L})$} \\
& 均值 & 范围 & 均值 & 范围 & 均值 & 范围 & 均值 & 范围 & 均值 & 范围 \\
\hline 湖心区 & 16.5 & $3.8-30.0$ & 2.61 & $0.78-6.40$ & 0.08 & $0.04-0.19$ & 9.71 & $2.16-23.3$ & 6.79 & $5.25-9.49$ \\
梅梁湾 & 16.8 & $4.2-30.0$ & 3.77 & $1.40-8.36$ & 0.09 & $0.04-0.20$ & 18.69 & $1.71-89.06$ & 8.67 & $3.61-57.91$ \\
河口区 & 17.9 & $5.0-29.3$ & 7.11 & $3.42-12.75$ & 0.24 & $0.11-0.56$ & 16.98 & $3.91-66.99$ & 8.12 & $0.07-16.09$ \\
\hline
\end{tabular}

\section{2 浮游细菌数量的季节变化}

不同湖区中细菌数量随季节的变化如图 2 所示. 从图中可以看出, 浮游细菌数量最小值出现在 3 月份 (均值为 $3.14 \times 10^{6} \mathrm{cells} / \mathrm{ml}$, 变化幅度 $2.39-5.36 \times 10^{6} \mathrm{cells} / \mathrm{ml}$ ), 从 3 月到 7 月, 细菌的数量呈明显上升趋 势, 并且在 7 月份达到最高值 (均值为 $7.43 \times 10^{6} \mathrm{cells} / \mathrm{ml}$, 变化幅度 $4.86-12.3 \times 10^{6} \mathrm{cells} / \mathrm{ml}$ ), 从 9 月至 11 月, 浮游细菌数量逐渐下降. 浮游细菌数量在河口区的变化有些异常, 这可能与河口区受外部干扰较大有 关. 总体上与太湖水体水华发生时间和水温的变化比较一致. 冬春季节太湖水体中浮游细菌数量与高温的 
夏季相比,最低值与最高值差异达 $73 \%$, 浮游细菌的这种季节变化特征与其它的同类研究结果基本 ${ }^{[11,12]}$.

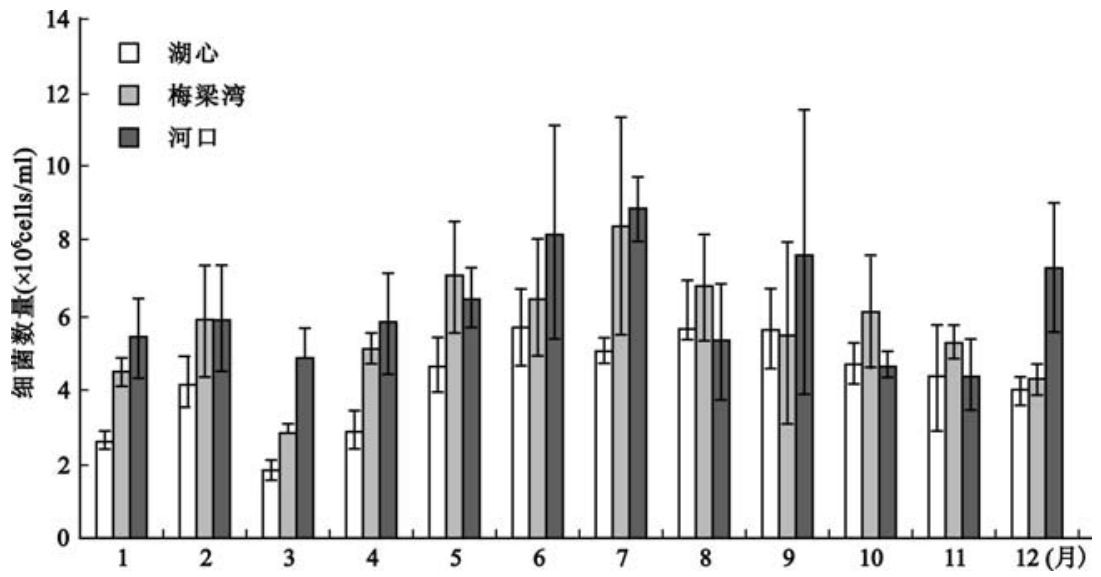

图 2 水体中浮游细菌数量年动态变化

Fig. 2 Variety of bacterioplankton in north of Lake Taihu

\section{3 浮游细菌数量的空间分异}

不同湖区浮游细菌数量的空间分布特征见图 3. 由下图可看 出, 浮游细菌数量在湖心区、梅粱湾和河口区具有明显水平分布 特征. 湖心区浮游细菌数量最低, 平均为 $3.31 \times 10^{6} \mathrm{cells} / \mathrm{ml}$, 变化 幅度 $1.56-6.33 \times 10^{6} \mathrm{cells} / \mathrm{ml}$, 梅粱湾浮游细菌数量平均为 4.32 $\times 10^{6} \mathrm{cells} / \mathrm{ml}$, 变化幅度 $3.11-6.58 \times 10^{6} \mathrm{cells} / \mathrm{ml}$, 河口区最高, 平 均为 $5.51 \times 10^{6} \mathrm{cells} / \mathrm{ml}$, 变化幅度 $3.96-7.63 \times 10^{6} \mathrm{cells} / \mathrm{ml}$; 呈现 出清晰的从湖心到河口逐渐递增的趋势, 方差分析显示, 湖心区、 梅梁湾与河口区差异显著 $(n=24, p<0.01)$.

\section{3 讨论}

\section{1 温度对浮游细菌数量的影响}

水温可能是影响水体中浮游细菌生长的主要因素 ${ }^{[13-15]}$, 太

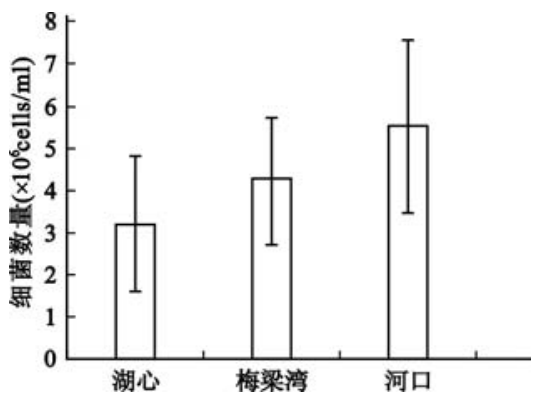

图 3 不同湖区浮游细菌数量分布

Fig. 3 Variation of bacterioplankton in different zone 湖地处亚热带地区, 冬夏温差较大, 2003 年水温的年变化范围为 $3.8-30.0^{\circ} \mathrm{C}$, 冬夏温差达 $23^{\circ} \mathrm{C}$ 以上. 浮游 细菌数量在水温较高夏秋季节比水温较低的冬春季节明显增加 (图 2), 原因可能是夏秋季节由于浮游植物 的大量繁殖, 浮游植物光合作用产生大量的可溶性有机物包括烃类、有机酸等为细菌提供了丰富的营养物 质 ${ }^{[16]}$. 另一方面, 可能是冬春季节水温相对较低,抑制了细菌了新陈代谢, 而夏秋季节水温较高, 促进了细 菌自身的新陈代谢加快了细菌的生长增殖速率.

从地理位置上看, 湖心区、梅梁湾与河口区处于同一纬度, 季节变化一致, 同期水温差别很小 $\left(<1^{\circ} \mathrm{C}\right)$. 但三个区域浮游细菌数量与水温相关性存在明显差异. 其中湖心区相关性最好 $\left(r^{2}=0.4206, n=24, p<\right.$ $0.01)$; 河口区最差 $\left(r^{2}=0.0492, n=24, p<0.298\right)$, 梅梁湾则介于两者之间 $\left(r^{2}=0.2661, n=48, p<0.001\right)$ (图 4). 产生这种差异的原因, 可能是河口区受人类活动干扰较大的缘故, $0^{\#} 、 6^{\#}$ 点分别位于梁溪河和直湖 港人湖口, 而梁溪河和直湖港是梅梁湾入湖污染物的主要来源, 带来无锡市和武进市大量工农业和生活污 水, 河水一方面携带丰富的营养物质, 并可能带来大量浮游细菌. 因而河口区细菌数量的多少很大程度上受 制于河流来水的影响, 从而干扰了浮游细菌数量于温度的相关性. 而在梅梁湾和湖心区由于受人湖河流携 带物质的影响逐渐减小. 


\section{2 营养盐对浮游细菌数量的影响}

氮、磷等物质是产生水体富营养化的主要原因,也是细菌生长繁殖不可缺少的营养成份. 研究表明,在 寡营养湖泊中,氮、磷等物质能单独或共同成为浮游细菌增殖的限制因素 ${ }^{[17,18]}$, 对中营养湖泊的研究结果 表明,碳,氮,磷的变化在不同的季节表现出不同的限制作用 ${ }^{[19]} .2003$ 年太湖北部湖区水环境监测结果表 明,三个区域中溶解性有机碳、总氮、总磷等营养物质含量存在较大差异, 而且存在明显的从湖心到河口区 逐渐增加的趋势. 与浮游细菌数量回归分析结果表明, 只有湖心区总氮, 总磷与浮游细菌数量 $\left(R^{2}=0.2288\right.$, $n=24, p=0.018),\left(R^{2}=0.1402, n=24, p=0.071\right)$ 存在微弱相关性. 其它区域中, 与浮游细菌数量都没有 明显的相关性, 这表明水体中的营养盐已完全能够满足浮游细菌的生长.
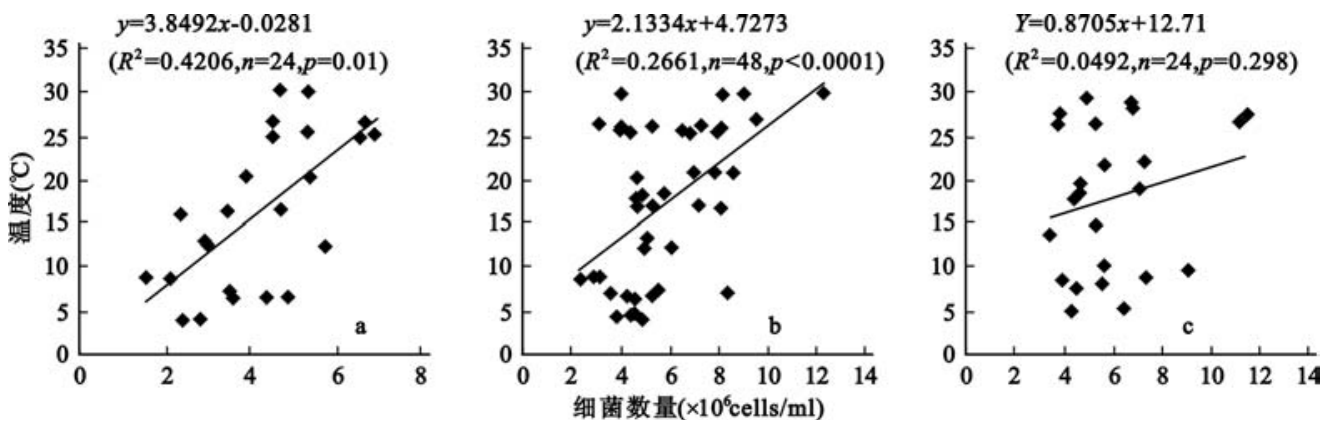

图 4 细菌数量随温度的变化 $(\mathrm{a}:$ 湖心区; $:$ 梅梁湾; $;$ : 河口区 )

Fig. 4 Variation of bacterioplankton according to water temperature

\section{3 浮游植物对浮游细菌数量的影响}

叶绿素 $\mathrm{a}$ 的含量可在一定程度上代表浮游植物生物量 ${ }^{[20]}$, 在富营养藻型水域中的食物网是受浮游植 物支配的 ${ }^{[21]}$. 另有研究表明, 水体微生物与水华的形成有密切的关系, 根据浮游细菌数量变化规律判断水 质变化情况, 可初步预测水华的发生 ${ }^{[5]}$, 可见浮游细菌的数量与浮游植物的生长密切相关.

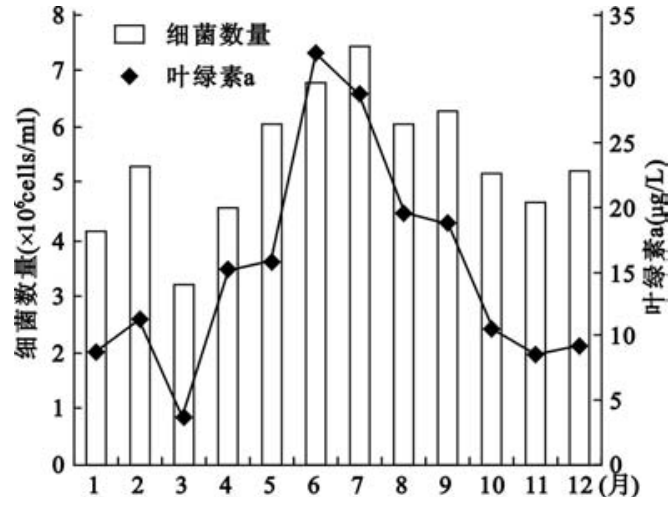

图 5 浮游细菌和叶绿 $\mathrm{a}$ 的动态

Fig. 5 Variation of bacterioplankton and Chl. a

太湖北部湖区浮游细菌数量与叶绿素 $\mathrm{a}$ 全年动态 变化趋势基本一致 (图 5 ). 浮游细菌和叶绿素 a 最大 值都发生在水温较高的夏季. 但浮游细菌的峰值滞后 于叶绿素 $\mathrm{a}^{[22,23]}$,太湖北部湖区是典型的富营养化藻 型湖区,每年从春季的 $4 、 5$ 月份开始就有浮游植物的 出现,并常常在气温较高的夏季达到高峰 ${ }^{[24]}$, 浮游细 菌与叶绿素 a 这种变化关系的可能原因是细菌所需要 的可溶性有机物部分来源于浮游植物降解所产生的可 溶性有机物, 而这些物质必须经过一定的积累,达到一 定的浓度后才可以供细菌生长 ${ }^{[28]}$. 这说明在太湖这样 一个富营养化的湖泊中, 水体中浮游细菌生长增殖所 需的有机碳可能部分来源于藻类的分解所产生的有 机物.

不同区域中叶绿素 $\mathrm{a}$ 含量对浮游细菌数量的影响 差异极大, 分别对湖心区、梅梁湾和河口区水体叶绿素 $\mathrm{a}$ 与浮游细菌数量关系作相关分析见图 6 . 其中湖心 区和河口区浮游细菌数量与叶绿素 $\mathrm{a}$ 的相关性较低 $\left(r^{2}=0.244, n=24, p<0.014\right)$, 梅梁湾中浮游细菌数量 则与叶绿素 $\mathrm{a}$ 显著相关. 导致以上结果的可能原因: 湖心区水域开阔,一方面风浪扰动引起底泥的再悬浮可 为浮游细菌的生长增殖提供部分营养物质, 另外, 风浪的作用会对浮游植物的分布产生影响, 从而掩盖了浮 游植物对浮游细菌的真实作用; 在河口区, 由于水流的冲刷作用及河水带人大量外源营养物质导致浮游植 
物现存量的变化, 这可能削弱浮游植物与浮游细菌之间的相关性. 水体中浮游细菌主要依靠浮游植物溶出 物作为碳源生长、增殖 ${ }^{[29]}$. 当叶绿素 $\mathrm{a}<50 \mu \mathrm{g} / \mathrm{L}$ 时, 随叶绿素 $\mathrm{a}$ 含量的增加, 水体中浮游细菌的也快速增 加 ${ }^{[25]}$, 在受外界干扰较小的梅梁湾中浮游细菌数量与叶绿素 $\mathrm{a}$ 的显著相关性也印证了这一观点. 由此我们 认为, 太湖水体中浮游植物产生的 DOC 是水体中浮游细菌的重要营养来源之一. 因此认为初级生产力是影 响太湖水体浮游细菌数量的重要因素.
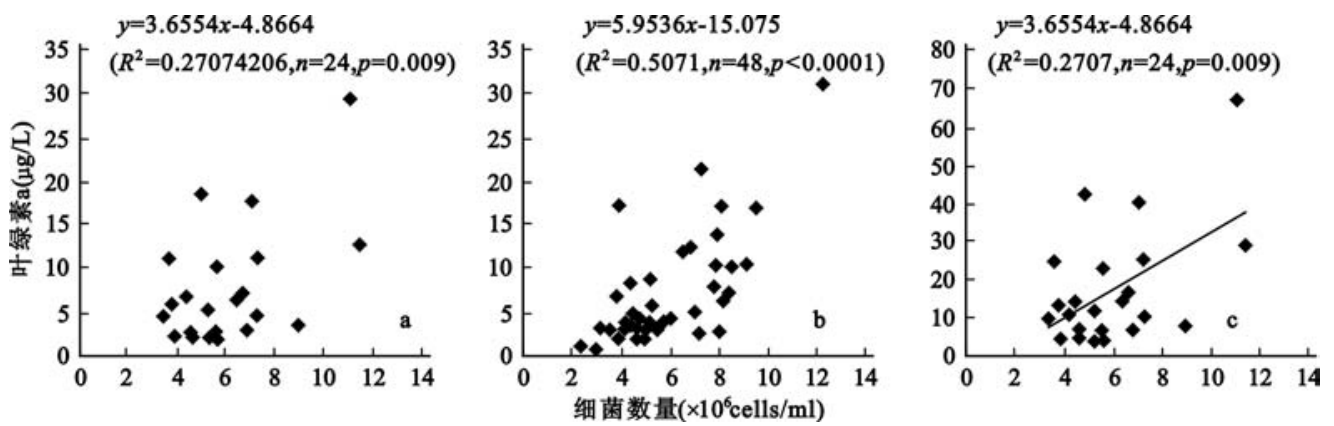

图 6 细菌数量与叶绿素 $\mathrm{a}$ 的线性相关

Fig. 6 Linear relationship between BA and Chl. a

\section{4 浮游细菌数量与叶绿素 a 和水温的综合关系}

水温是影响水体中浮游细菌生长增殖的一个重要生态因子, 而浮游植物又是浮游细菌生长过程中营养 物质的主要来源. 对浮游细菌数量与叶绿素 $\mathrm{a}$ 和水温关系做二元回归:

$$
B A=0.033 T+0.079 \text { Chla }+3.572\left(r^{2}=0.66\right)
$$

式中, $T$ 为温度 $\left({ }^{\circ} C\right)$, Chla 为叶绿素 $\mathrm{a}(\mu \mathrm{g} / \mathrm{L})$.

由上式可以看出: 浮游细菌数量主要受水温和叶绿素 $\mathrm{a}$ 的共同控制 $\left(r^{2}=0.66\right)$; 在太湖水温和叶绿素 $\mathrm{a}$ 的变化范围内,当叶绿素 $\mathrm{a}$ 每改变 1 个单位对浮游细菌数量变化的影响比水温改变 1 个单位对浮游细菌数 量的影响要高出 2.4 倍. 这表明, 温度虽是浮游细菌生长的重要的生态因子,但它对水体中细菌增殖的间接 作用更明显. 当水温升高时, 的确加速了细菌的代谢速率, 然而温度升高促使浮游植物大量生长, 光合作用 增强, 导致水体中各类有机物质含量的增加, 而有机营养物质增加对细菌的增殖起到更明显的促进作用.

\section{3 结论}

(1) 太湖梅梁湾水体中浮游细菌数量在不同的季节存在显著差异,夏、秋季节浮游细菌的数量较高, 冬、春较低,受温度影响显著.

(2) 浮游细菌数量的变化与叶绿素 $\mathrm{a}$ 之间存在明显的相关性,浮游细菌的变化速率滞后于叶绿素 $\mathrm{a}$ 的 变化,细菌生长过程中的碳源可能主要来自浮游植物本身的降解所带来的营养物质.

(4) 在太湖水体中,水温和浮游植物是控制浮游细菌变化的主要因素,浮游植物的作用更明显.

(5) 太湖北部湖区富营养化程度较高, 氮磷等营养物质已不成为浮游细菌生长的限制因素; 但随营养 物质含量的升高水体中异养细菌数量增加.

\section{4 参考文献}

[1] Scaria D. On the role of bacteria production. Limnol Oceanogr, 1988. 33(5):220 - 224 .

[2] Azam F, Fenchel T, Field J G, et al. The ecological role of water column microbes in the sea. Mar Ecol Prog Ser, $1983, \mathbf{1 0}: 257-263$.

[3] Walliams P J, Le B. Incorporation of microheterotrophic process into the classical paradigm of 5 planktonic food web. Kieler Meresforschungen, 1981,5(1):1-28. 
[4] Stockner J G, Antia N J. Algal picoplankton from marine and fresh water ecosystem: a multidisciplinary perspective. Can J Fish Aquat Sci, 1986, $43: 2472$ - 2503.

[5] David A, Caron Ee Lin Lin, Robert W, et al. Responses of bacterioplankton and phytoplankton to organic carbon and inorganic nutrient additions in contrasting oceanic ecosystems. Aquat Microb Ecol, 2000 ,22 : 175 -184 .

[6] 肖 天. 海洋浮游细菌的生态学研究. 地球科学进展, 2001,16(1): 60 - 64.

[7] Dufour P, Torreton J P L Colon M. Advantages of distinguishing the active fraction in bacterioplankton assemblages : some examples. Hydrobiologia, 1996,207 : $295-301$.

[8] 秦伯强, 胡维平, 陈伟民编著. 太湖水环境演化过程与机理. 北京:科学出版社, 2004.

[9] 金相灿，屠清瑛. 湖泊富营养化调查规范. 第二版. 北京: 中国环境科学出版社, 1990 .

[10］孙顺才, 黄渏平主编. 太湖. 北京:海洋出版社, 1993.

[11] Veljo Kisand, Tiina Noges. Abiotic and biotic factors regulating dynamics of bacterioplankton in a large shallow lake. Microbiology Ecology, 2004,50:51 - 62 .

[12] Cavallo R A, Rizzi C, Vozza T, et al. Viable heterotrophic bacteria in water and sediment in Mar Piccolo of Taronto, Italy. J Appl Microbial, 1999, 86(6):906-916.

[13] 白 洁, 李崩然, 李正炎等. 渤海春季浮游细菌分布与生态环境因子的关系. 青岛海洋大学学报, $2003,33: 841-846$.

[14] Ruben Sommaruga et al. Seasonal variability of metabolically active bacterioplankton in the euphotic zone of a hypertrophic lake. Aquat Microb Ecol. ,1997,13:241 - 248.

[15] Li W K W, Dickie, P M. Temperature characteristics of photosynthetic and heterotrophic activities: seasonal variations in temperate microbial plankton. Appl Environ Microbiol, 1987,53:2282 - 2295.

[16] Jennifer C, Jennifer C, James A AE, Ellen T M. Utilization and turnover of labile dissolved organic matter by bacterial heterotrophs in eastern North Pacific surface water. Mar Ecol Prog Ser, 1996,139:267 - 279.

[17] Morris D P, Lewis W M Jr. Nutrient limitation of bacterioplankton growth in Lake Dillon, Colorado. Limnol Oceanogr, $1992,37: 1179-1192$.

[18] Wang L, Miller T D, Priscu J C. Bacterioplankton nutrient deficiency in a eutrophic lake. Arch Hydrobiol, $1992,125: 423-439$.

[19] Toolan T, Wehr I D, Findlay S. Inorganic phosphorus stimulation of bacterioplankton production in a meso eutrophic lake. Appl Environ Microbiol. 1991, 57:2074 - 2078.

[20] Harris G P. Picoplankton Ecology, Structure, Function and Fluctuations. Chapman and Hall, 1986: 221 -235 .

[21] Dortch Q and Packard T. Differences in biomass structure between oligotrophic and eutrophic marine ecolosystems. Deep-Sea Res, $1989, \mathbf{3 6}: 223-240$.

[22] Fukami K, Muriyuki N, Morio Y, et al. Distribution of heterotrophic nanoflagellates and their importance as the bacterial consumer in a eutrophic coastal seawater. Journal of Oceanography, 1996, 52 : 399 - 407.

[23] Kirchman D L, Keil R G, Simon M, et al. Biomass and production of heterotropic bacterioplankton in the oceanic subarctic pacific. Deep-Sea Res, I, 1993, 40(5) : 967 - 988.

[24] 张运林,秦伯强等. 太湖梅梁湾浮游植物叶绿素 $\mathrm{a}$ 和初级生产力. 应用生态学报, 2004,15(11):2127 -2131 .

[25] Del Gilrgio P A, Scaborough G. Increase in the proportion of metabolically active bacteria along gradients of enrichment in freshwater and marine plankton: implications for estimates of bacterial growth and production rates. Plankton Res, 1995,17 :1905 - 1924. 